УДК 001: 316.77

Petrushka Alina,

$\mathrm{PhD}$ in Social Communication Leading specialist of Scientific Library of

Lviv Polytechnic National University alina.stashko@gmail.com orcid.org/0000-0002-8769-4599

Peleshchyshyn Andriy, Doctor of Technical Sciences, Professor, Head of Department of Social Communication and Information Science of Lviv Polytechnic National University apele@ridne.net orcid.org/0000-0002-5022-0410

\title{
ALGORITHM FOR PROMOTION OF UNIVERSITY EDITIONS INTO THE SCIENTOMETRIC DATABASES
}

The purpose of the article is to highlight the main principles and results of the implementation of the library information service on the promotion of scientific journals into the scientometric databases. To achieve the goal, the main tasks were to determine the preconditions for the implementation of the innovative services by the university library; to develop an algorithm of scientific journals promotion into the scientometric databases; to analyze the effectiveness of the implementation of the specified service. The methodology involves the use of several general scientific methods: logical analysis, synthesis, statistical method, and the method of results visualization. The scientific novelty of the work consists in the formation of a functional scheme of information services of the library on the promotion of scientific journals into the scientometric databases. Conclusions introduce information service that involves scientific and consulting activities aimed at integrating the academic editions into the international scientific information space. The implementation of the service was carried out through the synergistic interaction of three participants: the editorial boards of the university scientific journals, the Scientific Library (SL), and the Research and Development Department (R\&D Department) of the Lviv Polytechnic. Within the service, the powers to perform specific processes are distributed among all participants. As a result, an algorithm for the promotion of scientific journals into the scientometrics databases was developed and worked out. During 2018-early 2019, scientific and methodical consultations were provided to editors of 18 journals founded by Lviv Polytechnic National University and the public organizations Lviv Analytic House and Western Geodetic Society. The coverage of the academic institutes of the Lviv Polytechnic with the service on the promotion of the journal into the scientometric databases makes 70\%. In general, since the introduction of the service in the first quarter of 2019, 27 requests were satisfied. The high activity of the editorial boards of the university's journals indicates the demand and effectiveness of the service.

Key words: scientific journal, scientometric database, editorial board, library, information service 
Петрушка Аліна Іванівна, кандидат наук із соціальних комунікацій, провідний спеціаліст Науково-технічної бібліотеки Національного університету «Львівська політехніка»

Пелещишин Андрій Миколайович, доктор технічних наук, професор, завідувач кафедри соціальних комунікацій та інформаційної діяльності Національного університету «Львівська політехніка»

\title{
АЛГОРИТМ ПРОСУВАННЯ УНІВЕРСИТЕТСЬКИХ ВИДАНЬ В НАУКОМЕТРИЧНІ БАЗИ ДАНИХ
}

\begin{abstract}
Метою роботи є висвітлення основних засад та результатів впровадження університетською бібліотекою інформаційної послуги із просування наукових видань до наукометричних баз даних. Методологія дослідження передбачає використання низки загальнонаукових методів: логічного аналізу, синтезу, статистичного методу та методу візуалізачї результатів дослідження. Наукова новизна роботи полягає у формуванні функиіональної схеми інформаційної послуги бібліотеки із просування наукових видань до наукометричних баз даних. Висновки. Науково-технічною бібліотекою Львівськоїполітехніки було впроваджено інформачійну послугу, щзо передбачає науково-консультативну діяльністьзметою інтеграиіїнаукових видань університетудоміжнародного наукового інформаційного простору. В результаті було відпрачьовано алгоритм просування наукових видань до наукометричних баз даних. Висока активність редакцій журналів університету свідчить про запропотребованість $i$ результативність послуги.
\end{abstract}

Ключові слова: науковий журнал, наукометрична база даних, редакційна колегія, бібліотека, інформаційна послуга

Петрушка Алина Ивановна, кандидат наук по социальным коммуникациям, ведущий специалист Научно-технической библиотеки Национального университета «Львовская политехника»

Пелещииин Андрей Николаевич, доктор технических наук, профессор, заведующий кафедрой социальных коммуникаций и информационной деятельности Национального университета «Львовская политехника»

\section{АЛГОРИТМ ПРОДВИЖЕНИЯ УНИВЕРСИТЕТСКИХ ИЗДАНИЙ В НАУКОМЕТРИЧЕСКИЕ БАЗЫ ДАННЫХ}

Цельюработыявляетсяосвещениеосновныхпринииповирезультатоввнедрения университетской библиотекойинформачионнойуслугипопродвижению научныхизданийвнаукометрическихбазы данных. Методология исследования предполагает использование ряда общенаучных методов: логического анализа, синтеза, статистического метода и метода визуализации результатов исследования. Научная новизна работы заключается в формировании функииональной схемы информационной услуги библиотеки по продвижению научных изданий в наукометрические базы данных. Выводы. Научнотехнической библиотекой Львовской политехники была внедрена информационная услуга, которая предусматривает научно-консультативную деятельность с иелью интеграции научных изданий университета вмеждународное научное информационное пространство. В результате был отработан алгоритм продвижения научных изданий в наукометрические базы данных. Высокая активность редакций журналов университета свидетельствует о востребованости и результативности услуги.

Ключевые слова: научный журнал, наукометрическая база данных, редакционная коллегия, библиотека, информаџионная услуга. 
Relevance of the research topic. The purpose of the work is to highlight the main principles and results of the implementation of the library information service on the promotion of scientific journals into scientometric databases. To achieve the goal, the main tasks are to determine the preconditions for the implementation of the innovative services by the university library; to develop an algorithm of scientific journals promotion into the scientometric databases; to analyze the effectiveness of the implementation of the specified service.

Analysis of recent research and publications. Today, university libraries carry out their activity in the conditions of constant transformation of their function and purpose appointment. New requirements for university libraries include their integration into general information infrastructures, which provides communication unity in the process of implementing the public functions of libraries [6]. Such a model of the library implies its direct participation in the educational and research activity of university through the introduction of innovative services. The list of such services is determined primarily by the flexibility of the library system, that is, the ability to identify and respond promptly to the emergence of new non-traditional information needs of users [2]. In particular, the task of the modern university library is not only the organization of free access to scientific information but also the integration of academic achievements into the international scientific information space $[7 ; 11]$.

The focus on European integration is due to the need for improvement of scientific publications' quality to ensure compliance with high international standards. At the present stage of scientific communication development, the editors of scientific journals are interested in the fact that their publication has been indexed by international databases. Publications in journals not included in international scientometric databases have no chance to reach the world scientific community. The problem areas of domestic university editions are their noninternational status due to the low percentage of foreign authors, reviewers, and English-language publications. The analysis of the academic scientific journals activity indicates the need to change the work technology of most editions [4; 5].

Topical problems are the organizational nature of the participation of academic journals in the general information space, since publishing on the Internet of scientific results makes them the property of the world scientific community, increases the level of communication and recognition. Minimizing content, insignificant volume and low quality of the information received by the consumer leads to a limitation of awareness and negatively reflects the application of the knowledge gained and the rating of the journal [3].

The use of modern information technologies, taking into account the actual trends in the development of scientific periodicals, is the only way to increase the "visibility" of the edition. Therefore, only parallel development of unified aggregated resources of scientific institutions of Ukraine can ensure the proper formation of a segment of academic publishing production [10].

Presentation of the main material. According to the Law of Ukraine "On Libraries and Library Affairs", the main task of the library is to provide information, research, educational, cultural and other needs of library users. Thus, users' needs are determining the range of services provided by the library (Fig. 1).

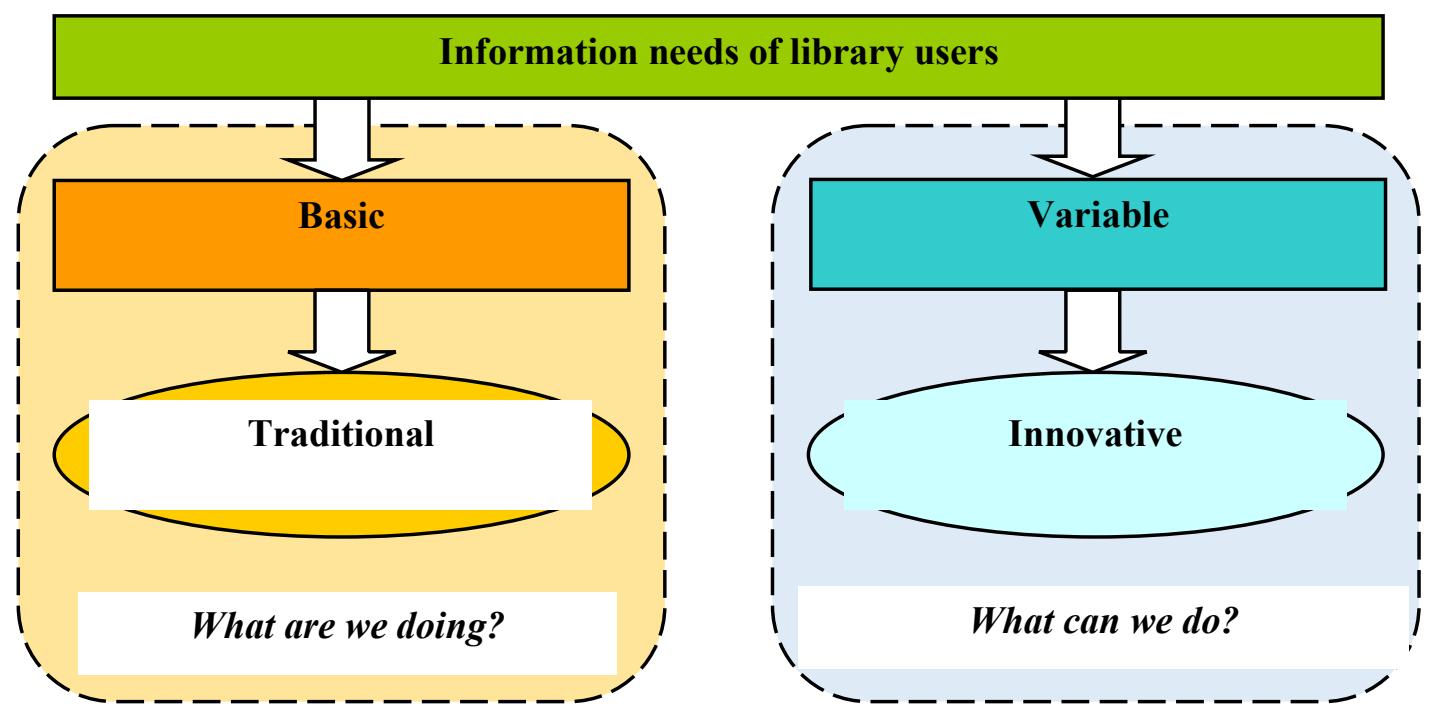

Fig.1. Formation of library services by the principle "the user is always right" 
The basic information needs of users are characterized by regularity in time. They form a list of traditional library services that provide access to library funds.

Variable information needs are characterized by dynamics and limited in time relevance. They determine a list of innovative library services, the implementation of which requires the use of non-standard approaches and tools.

In the system of scientific communication, university and public libraries operate in somewhat different planes. The special status of the university library provides its direct participation in the provision of research activity. In the context of the globalization of the information space, domestic science undergoes significant transformations related to obtaining compliance with international standards. This greatly expands the range of variable information needs of scholars due to the need for adaptation and integration of the scientific activity results in the international scientific information space. Implementation effectiveness of the university library functional purpose in the aspect of the introduction of the innovative service depends directly on the timely identification of the actual variable information needs of users. The identification process involves constant and qualitative monitoring of the field of scientific activity, taking into account its current state and external influences.

Preconditions for the introduction of service on the promotion of scientific journals into the scientometric databases. An important stage in scientific research is the publication of its results. Today, the real trends in the field of the publication of scientific achievements are as follows:

- publication of research results of the university professors in journals indexed in databases Scopus, Web of Science and other databases recognized as scientometric;

- inclusion of scientific journals into authoritative international scientometric databases.

The indexing of the scientific journal in the scientometric databases is evidence of its author- ity and prestige. However, for the domestic scientific periodicals since January 2018, inclusion in the international information space has become a vital necessity. After all, under the new conditions for acquiring the status of a professional scientific edition, indexation in scientometric databases is a prerequisite [8].

Editorial boards faced with the need for radical changes in editorial policy in all aspects of the functioning of scientific journals. The complexity of the realization of the given task is substantially increased also by the limited time because adaptation to new requirements needs to be carried out by 2020 .

In the context of this issue, the Scientific Library of the Lviv Polytechnic National University (SL) in February 2018 introduced the service "Promotion of the journal into the scieneometric databases", which consists of scientific and consulting support and cooperation with editors on the inclusion of scientific editions assigned to academic institutes and departments of the University to the databases Scopus, Web of Science and Index Copernicus.

Implementation of service on the promotion of university journals into the scientometric databases. Promotion of a scientific journal into the scientometric databases involves checking its compliance with international standards. Based on the analysis of the Scopus, Web of Science (WoS) and Index Copernicus requirements, the conceptual foundations of the functioning of scientific journals in the conditions of integration into the international information space were formed [1]. By comparing the current characteristics of the journal with conceptual characteristics, inconsistencies were identified, and actions to eliminate them were taken.

The implementation of the service was carried out through the synergistic interaction of three participants: the editorial boards of the university scientific journals, the SL and the Research and Development Department (R\&D Department) of the Lviv Polytechnic (Fig. 2). 


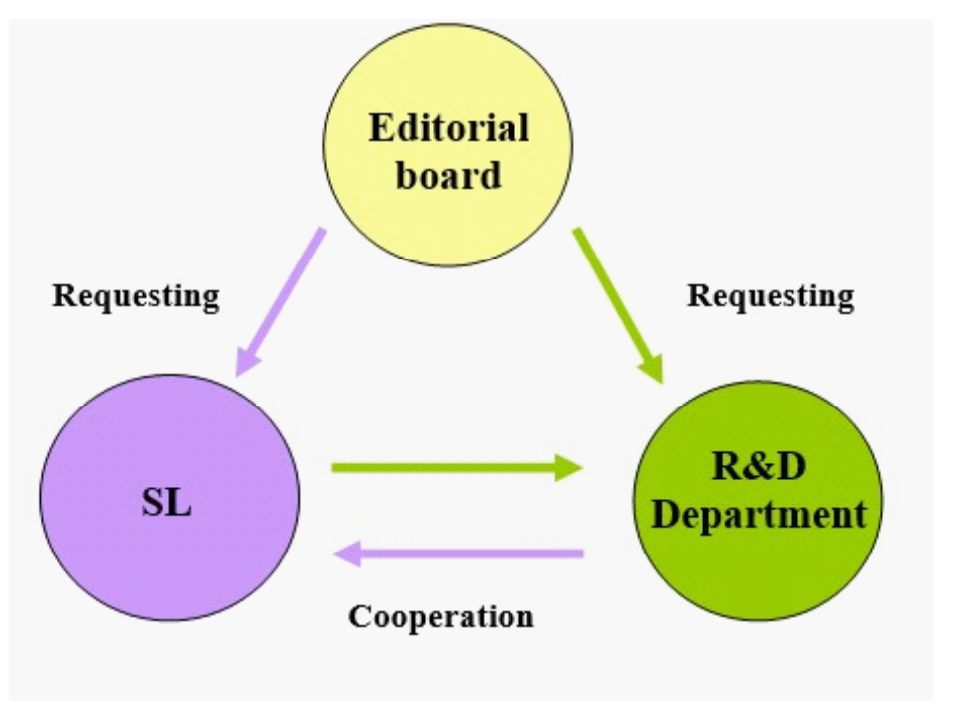

Fig. 2. Participants of the promotion of the scientific journal into scientometric databases

Within the service, the powers to perform specific processes are distributed among all participants.

SL's powers include the execution of follows processes:

- formation of recommendations for actualizing the scientific journals under the requirements of scientometric databases;

- assigning serial edition's identifier ISSNprint and -online;

- consulting/documentation support for requesting inclusion into scientometric databases.
R\&D Department's specialists assign the digital object identifier DOI to a scientific journal.

Within the responsibility of the editorial board there are:

- submission of a request for the service;

- implementation of the recommendations received to update the scientific journal under the requirements of the scientometric databases;

- submission of an application for inclusion in scientometric databases (Fig. 3). 


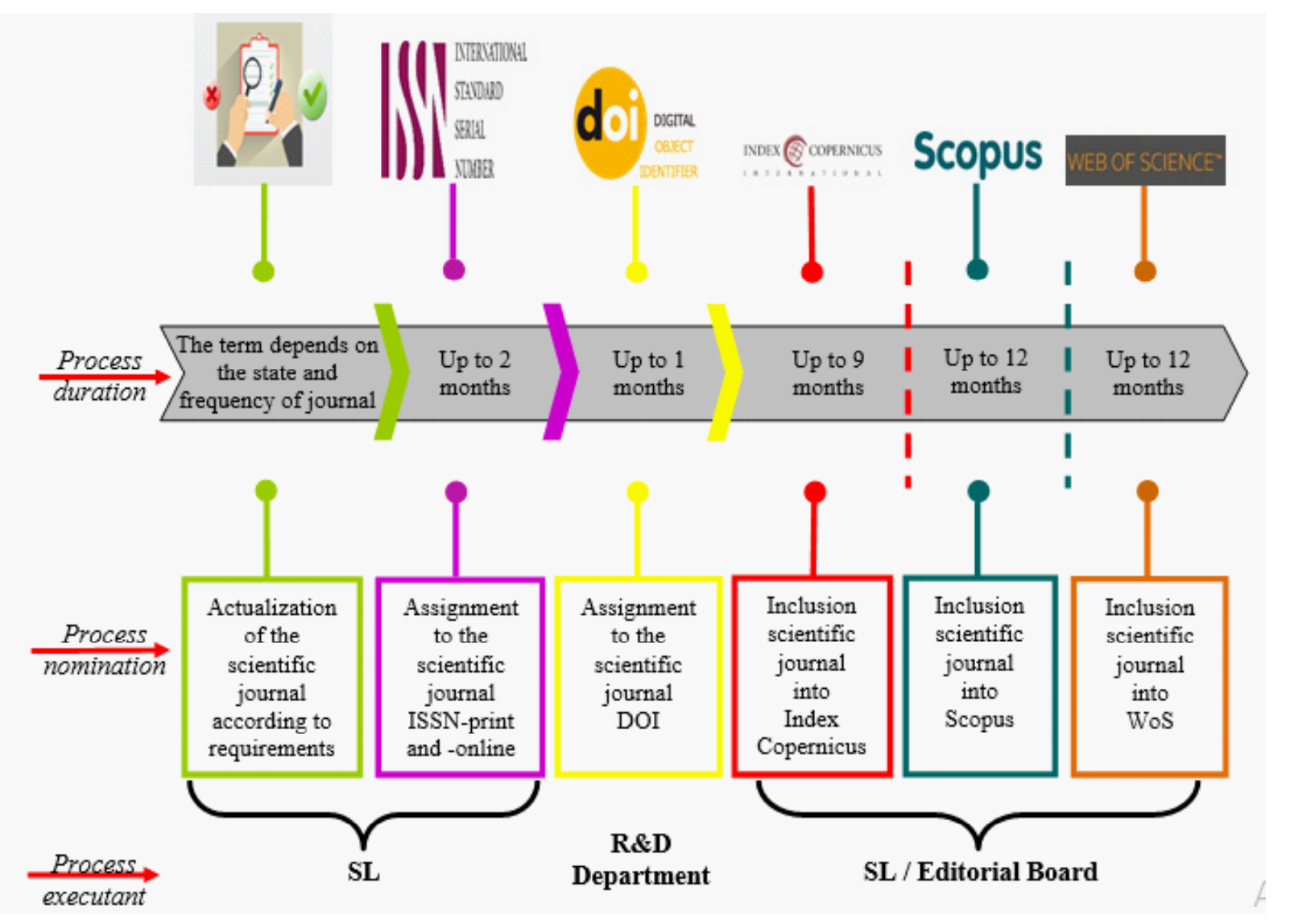

Fig. 3. The functional scheme of the service life cycle

The involvement of the R\&D Department in the realization of service is because this unit directly supervises the activity of scientific journals, assigned to academic institutes and departments of Lviv Polytechnic. That is why a significant part of the editorial boards' initial requests concerning the promotion of the journals into the scientometric databases comes to the R\&D Department and after redirects to the library. In turn, the library redirects requests to the R\&D Department to execute processes within the powers of this participant.

For the convenience of users on the official website of the library, there is an online form for requesting individual consultation on the promotion of the journal into the scientometric databases (Fig. 4). 


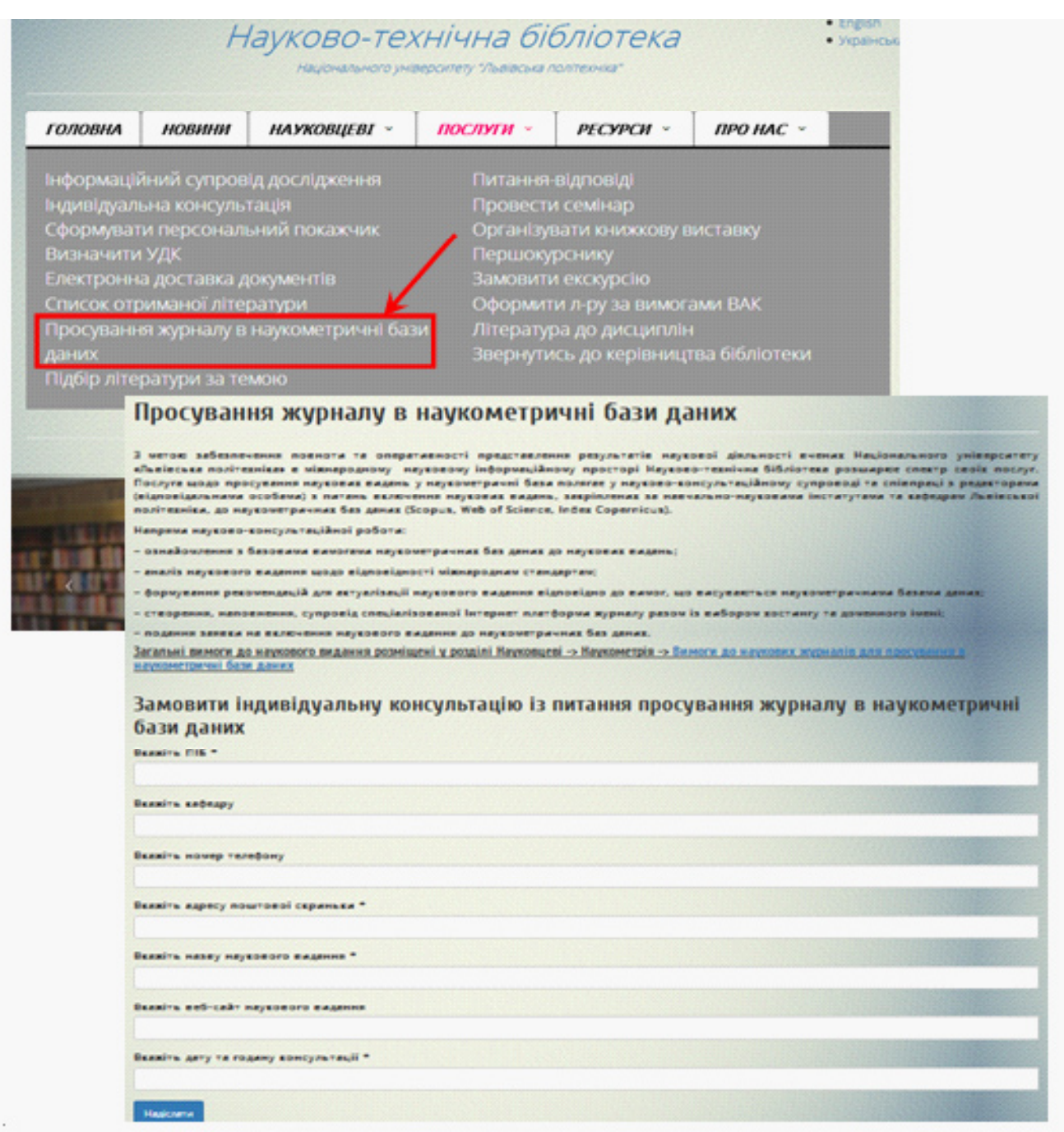

Fig. 4. Online form for requesting individual consultation on the promotion of the journal to scientometric databases [9]

The actualization of the journal under the developed conceptual model of the scientific publication includes the following types of scientific and consulting activities:

- getting to know the requirements of scientometric databases to scientific journals;

- getting to know the requirements of CrossRef to the website of a scientific journal to obtain a DOI;
- content analysis of scientific journal and their websites in compliance with international standards;

- the formation of recommendations package for updating the journal under the developed concept of the scientific edition (Fig. 5). 


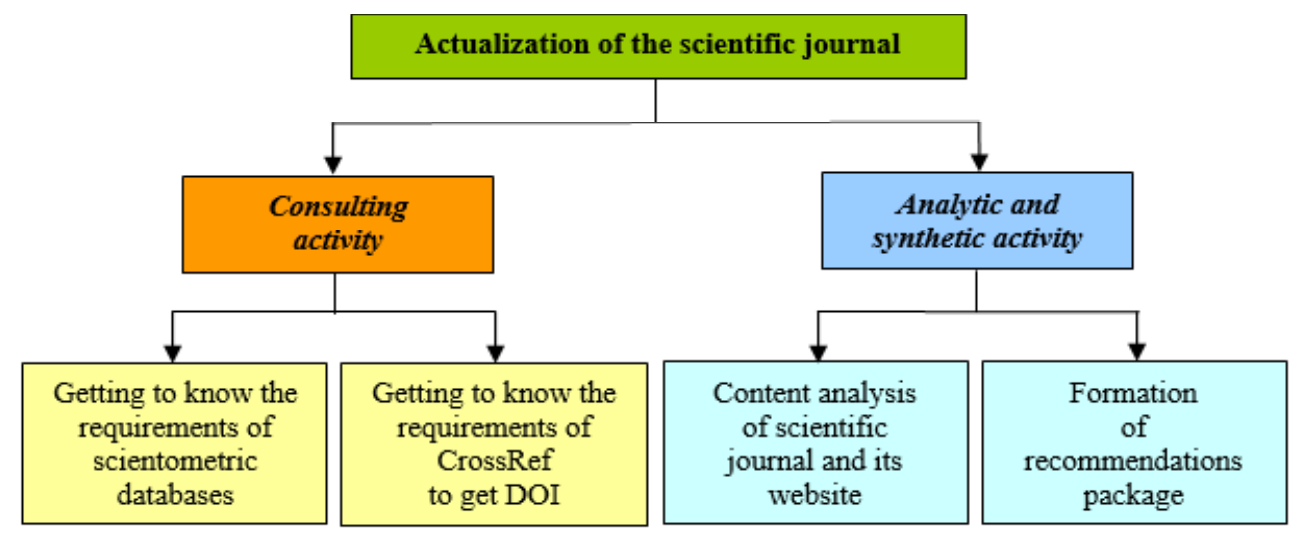

Fig. 5. Activities for actualizing scientific journal

The main areas of documentation and consulting activity within the service are:

- assignment of ISSN identifiers;
- inclusion of the journal into scientometric databases (Fig. 6).

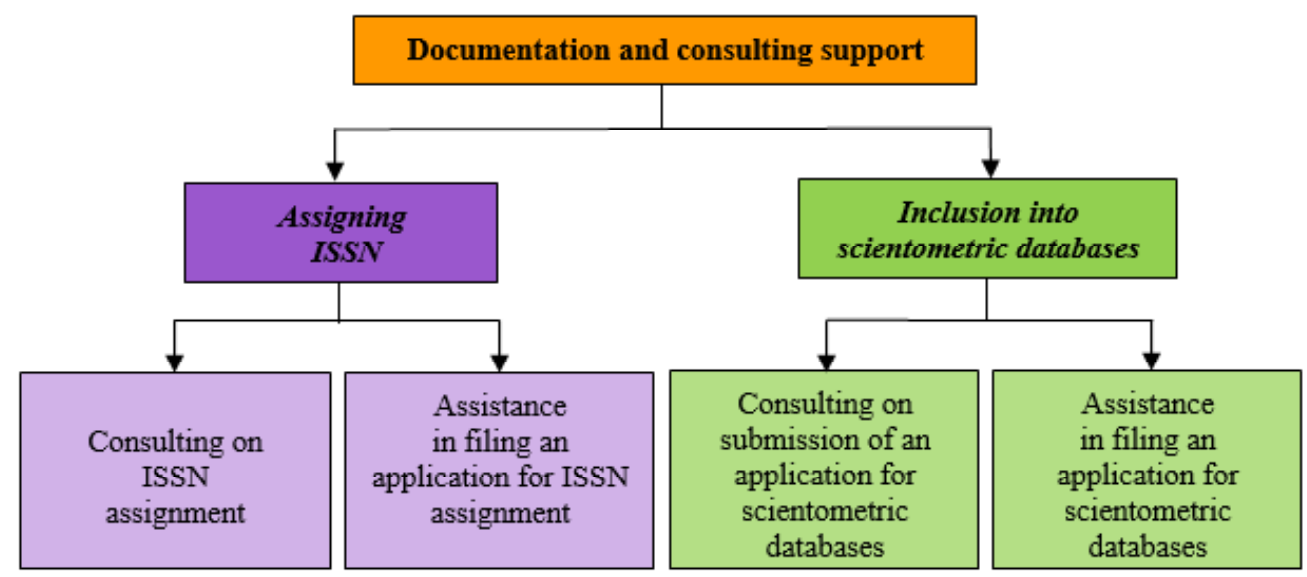

Fig. 6. Activities for documentation and consulting support

The effectiveness of the service on the promotion of the journal into the scientometric databases. During 2018 - early 2019, scientific and methodical consultations were provided to editors of 18 journals founded by Lviv Polytechnic Na- tional University and the public organizations Lviv Analytic House and Western Geodetic Society.

The coverage of the academic institutes of the Lviv Polytechnic with the service "Promotion of the journal into the scientometric databases" 
makes $70 \%$ (12 out of 17$)$. So, in 2018, SL actively collaborated with Institute of the Humanities and Social Sciences, Institute of Jurisprudence and Psychology, Institute of Computer Technologies, Automation and Metrology, Institute of Computer Science and Information Technologies, which submitted for promotion 2 journals each one, and Institute of Geodesy, Viacheslav Chornovil Institute of Sustainable Development, Institute of Economics and Management, Institute of Power Engineering and Control Systems, Institute of Engineering Mechanics and Transport, which submitted for promotion 1 magazine each one. Requests of editorial boards related to issues of compliance of journals with the requirements of international standards.
In 2019, the format of cooperation went out to a qualitatively different level: next to the journals submitted for the first time (Institute of Architecture submitted 3 journals, Institute of Building and Environmental Engineering and Institute of Chemistry and Chemical Technologies submitted 1 journal each one), there was a tendency for further cooperation with already actualized in 2018 editions. The editorial boards have requested second content-analysis, as well as documentation support for applying inclusion into scientometric databases.

In general, since the introduction of the service in 2018, 15 requests of editorial boards were met; as of the end of the first quarter of $2019-12$ requests (Fig. 7).

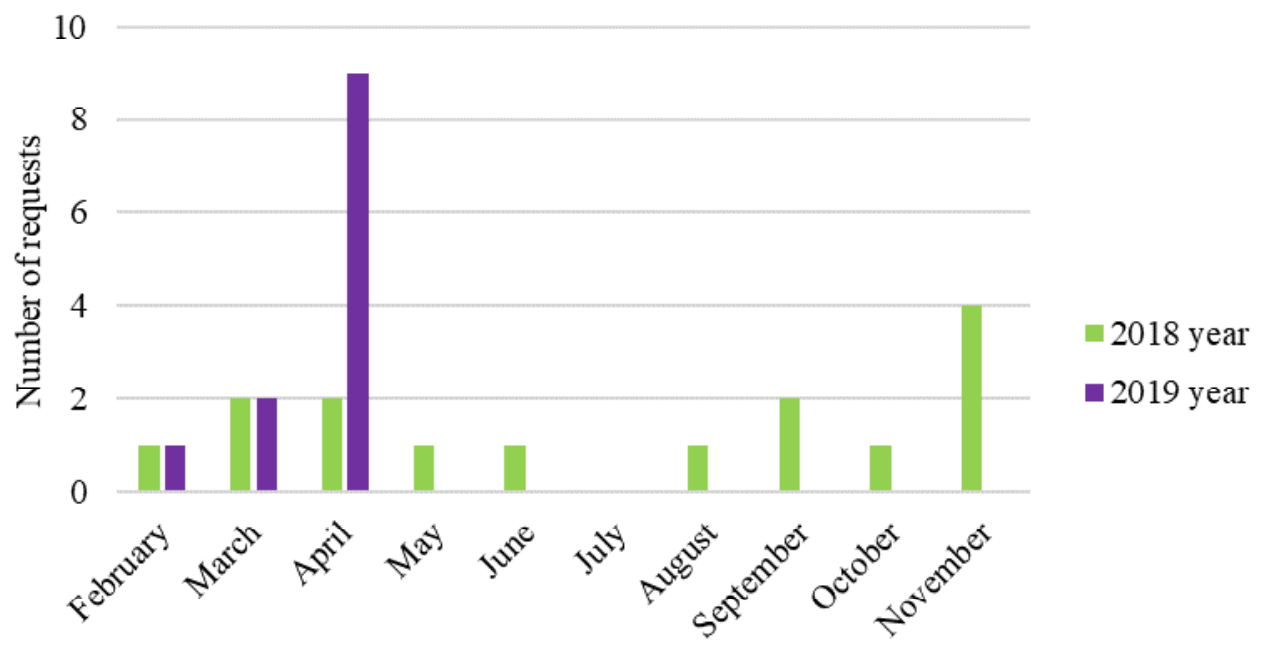

Reporting period

Fig. 7. The satisfaction of requests within the framework of the "Promotion of the journal into scientometric databases" service

The obtained statistical data testify to the active role of SL in integrating the scientific periodicals of Lviv Polytechnic into the international scientific information space.

Conclusions. The list of innovative services of the library is determined by dynamic and limited in time relevant user's variable information needs, which require constant and qualitative monitoring.

In keeping with the need for indexation in international scientometric databases, the Scientific Library has introduced a service that involves scientific and consulting activity aimed at integrating scientific journals founded by the Lviv Polytechnic
National University into the international scientific information space. As a result, an algorithm for the promotion of scientific editions into scientometric databases was worked out, which reflects by the developed concept of a scientific journal and the functional scheme of information services.

The high activity of the editorial boards of the University's journals indicates the demand and effectiveness of the service. The synergy of efforts of university collectives and library contributes to the positive dynamics of the integration of domestic scientific achievements into the world scientific space. 


\section{Список використаних джерел}

1. Андрухів А. І., Петрушка А. І. Концепція наукового журналу в умовах інтеграції в міжнародний інформаційних простір. Бібліотекознавство. Документознавство. Інформологія. 2018. № 3. С. 15-23.

2. Білоус В. Діяльність бібліотеки вищого навчального закладу щодо адаптації університетської науки у світовий інформаційний простір. Сучасні підходи до управління підприємством : матеріали наук.-практ. конф. Вінниця, 2016. С. 24-33.

3. Грабовська О. С., Грабовська О. С., Пилипець А. 3., Сачко Р. Г., Смоляні нова О. О. Участь періодичних наукових фахових видань у загальному інформаційному науковому просторі. Передгірне та гірське землеробство і тваринництво. 2013. № 55 (1). С. 210-221.

4. Діденко Ю. Академічна наукова періодика в системі сучасної комунікації Наука Украӥни у світовому інформаційному просторі. 2014. Вип. 10. С. 11-18.

5. Діденко Ю., Язвинська М.Перспективи входження академічних наукових видань до наукометричних баз даних. Наука Украйни у світовому інформаційному просторі. 2017. Вип. 14. С. 61-67.

6. Колесникова Т. Сучасна бібліотека ВНЗ: моделі розвитку в умовах інформатизації. Бібліотекознавство. Документознавство. Інформологія. 2009. № 4. С. 57-62.

7. Лота Т. Науково-інформаційна діяльність бібліотек: до постановки питання. Бібліотечний форум: історія, теорія і практика. 2015. № 2 (2). С. 38-42.

8. Про затвердження Порядку формування Переліку наукових фахових видань України» : наказ M-ва освіти і науки України від 15 січня 2018 р. № 32. URL: https:/cutt.ly/tthy61 (дата звернення: 02.02.2019).

9. Просування журналу в наукометричні бази даних. Науково-технічна бібліотека : веб-сайт. URL: http://library.lp.edu.ua/uk/prosuvannya-zhurnalu-v-naukometrychni-bazy-danyh (дата звернення: 10.07.2019).

10. Радченко А. И., Денисенко А. Е. Развитие информационных веб-ресурсов на базе ИД Академпериодика НАН Украины. Библиотеки национальных академий наук: проблемы функиионирования, тенденции развития. 2016. № 13. С. 197-205.

11. Сухарєва Л. Інтеграція ікомунікація ресурсів бібліотек внзу формуваннінауково-інформаційного. Сучасні підходи до управління підприємством : матеріали наук.-практ. конф. Вінниця, 2016. С. 4-11.

\section{References}

1. Andrukhiv A., Petrushka A. (2018). Concept Of Scientific Journal In Conditions Of Integration Into The International Informational Space. Bibliotekoznavstvo. Dokumentoznavstvo. Informolohiia. 3, 15-23. [in Ukrainian]

2. Bilous V. (2016). The activity of the library of the higher educational institution on the adaptation of university science into the world information space. Nauk.-prakt. konf. Suchasni pidkhody do upravlinnia pidpryiemstvom. Vinnytsia. [in Ukrainian]

3. Hrabovska O.S. (2013). Participation of periodical scientific professional editions in the general informational scientific space. Peredhirne ta hirske zemlerobstvo i tvarynnytstvo. 55 (1), 210-221. [in Ukrainian]

4. Didenko Yu. (2014). Academic scientific periodicals in modern communication system. Nauka Ukraïny u svitovomu informacijnomu prostori. 10, 11-18. [in Ukrainian]

5. Didenko Yu., Yazvinska M. (2017). Prospects of entry of academic scientific publications to scientometric databases. Nauka Ukraïny u svitovomu informacijnomu prostori. 14, 61-67. [in Ukrainian]

6. Kolesnykova T. (2009). Modern university library: models of development in the conditions of informatization. Bibliotekoznavstvo. Dokumentoznavstvo. Informolohiia. 4, 57-62. [in Ukrainian]

7. Lota T. (2015). Scientific and information activities of libraries: to question setting. Bibliotechnyi forum: istoriia, teoriia i praktyka. 2 (2), 38-42. [in Ukrainian]

8. Ministry of Education and Science of Ukraine. Order No. 148/31600, On Approval of the Procedure for the Formation of the List of Scientific Professional Publications of Ukraine. Retrieved from https://cutt.ly/ tthy61. [in Ukrainian]

9. Scientific Library. Promotion of the journal into the scientometric databases. Retrieved from http:// library.lp.edu.ua/uk/prosuvannya-zhurnalu-v-naukometrychni-bazy-danyh. [in Ukrainian]

10. Radchenko A.Y., Denysenko A.E. (2016). Development of information web resources based on the Academic Periodika of the National Academy of Sciences of Ukraine. Byblyoteky natsyonalnukh akademyi nauk: problemы funktsyonyrovanyia, tendentsyy razvytyia. 13, 197-205. [in Russian]

11. Sukharieva L. (2016). Integration and communication of university libraries' resources in the formation of scientific information space. Nauk.-prakt. konf. Suchasni pidkhody do upravlinnia pidpryiemstvom. Vinnytsia. [in Ukrainian] 